\title{
Researching migrant entrepreneurship communities: a reflection through collaborative (auto)ethnographies
}

\author{
Natalia Vershinina ${ }^{1}$ (D) Allan Discua Cruz $^{2}$
}

Accepted: 6 November 2020/ Published online: 26 November 2020

(C) Springer Science+Business Media, LLC, part of Springer Nature 2020

\begin{abstract}
In this paper we offer a scholarly reflection about the value of ethnographic methods for studying migrant entrepreneurship; this reflection is seen specifically through the lens of our own migration experiences. Our positionalities and subjectivities, embedded in being migrants and researchers, offer this opportunity for in-depth reflection. Specifically, we examine what varieties of ethnographic research methods offer, as well as what limitations these methods bring if adopted within migrant entrepreneurship research. We argue that specific ethnographic practice-based methods have the capacity to reveal the rich social context of migrant entrepreneurship, which can supplement the theoretical perspectives. We adopt two illustrations to highlight the relevance of ethnographic methodologies to studying migrant entrepreneurship. The contribution this study offers is in suggesting new methods that allow fresh understanding of the complex narratives of migration dynamics to emerge. This study shows how narratives intertwine with migrants' stories of entrepreneurship and offers guidance for future research.
\end{abstract}

Keywords Migrant entrepreneurship · Autoethnography · Ethnography · Reflexivity · Researcher positionality · Context

\section{Introduction}

The field of migrant entrepreneurship is mature. It builds on the work of numerous sociologists and anthropologists, whose insight on structure and agency (Giddens

Natalia Vershinina

nvershinina@audencia.com

Allan Discua Cruz

a.discuacruz@lancaster.ac.uk

1 Department of Business and Society, Audencia Business School, Nantes 44312, France

2 Department of Entrepreneurship and Strategy, Lancaster University Management School, Bailrigg LA14YX, UK 
1984), acculturation (Light et al. 1994; Portes and Jensen 1989), forms of capital (Ram et al. 2008; Vershinina et al. 2011; Discua Cruz and Fromm 2019), with special focus on ethnicity and social capital (Barrett and Vershinina 2017), and the latest theory of mixed embeddedness (Kloosterman et al. 2016; Kloosterman et al. 1999), highlight how migrants engage a set of resources to fit their ventures within the institutional, political, and regulatory environment. Whilst the empirical work illuminating how migrant entrepreneurial actors from different ethnic groups and countries settle in new host environments engages a variety of methodologies, studies very rarely reflect upon the role of the researcher within such scholarly works.

This study questions the potential of ethnographic methodologies for studying migrant entrepreneurship by recognising the specificity of researcher experiences in developing an understanding of migrants' occupational choices and practices, and, specifically, how researchers treat their subjects of research during the ethnographic study, as well as how they perceive the complexity of the context shaping migrant entrepreneurship. Whilst the use of various methods in the study of migrant entrepreneurship has advanced substantially, most of the methodological approaches adopted rely on quantitatively collected data, which funnels a specific set of perspectives and approaches (see Rodríguez-Pose and von Berlepsch 2020, or Wei and Zhu 2020). In an attempt to generalise from the data, quantitative works may come across as disconnected from the reality of migration experience, thereby disregarding the complexity of dual contexts of countries of origin and countries of destination entanglements for migrant entrepreneurship. In contrast, qualitative studies of migrant entrepreneurship tend to focus on the migration context, showcasing an in-depth understanding of heterogeneous ways in which migrants engage in entrepreneurship, but such works get criticised for their lack of theoretical generalization.

In this article we focus on the use of ethnography and reflect on its applicability for studying migrant entrepreneurship. Ethnography is a methodology that refers to practices in which researchers spend long periods of time immersed within cultural groups in order to study the patterns and systems of their everyday life (Parker-Jenkins 2018, p. 19). Moreover, to contribute to the understanding of migrant entrepreneurship through ethnography, in this paper we examine the research methods adopted within studies of migrant entrepreneurship and present an evaluation of the methods that have the potential to portray migrant entrepreneurship journeys in a more authentic manner. As such, this article is also an example of collaborative auto-ethnography, as we - as authors and researchers - draw on our own expertise as an "interdisciplinary team" (Chang 2013, 2016). This method allows for reflection on existing theories and methods in the latest publications in the field of migrant entrepreneurship.

In this article we tackle an important question, which we have been grappling with ourselves as researchers: does a researcher have to be a migrant themself in order to design research studies on migrant entrepreneurship? If a researcher is a migrant, does it help them to uncover what it means to be a migrant entrepreneur, and in doing so to retain their voice in the story? Whilst there are two opposing polemic views on the above-named matter, for some of us subjectivity may be a problem, whilst for others it may not. We might even argue that by being familiar with the research context we may be able to see what we expect to see, and therefore produce subjective outcomes. Moreover, at the same time we may argue that total engagement and immersion in a research context may offer the opportunity to be very close to the 
research subjects, and potentially more objective in re-telling our experiences. The research question in this study also resonates with some of the traditional debates about who has a better view of the world: for instance, can a non-entrepreneur (academic) write about entrepreneurship, if they do not have experience of starting and running a business themselves? Can a psychiatrist, who is sane, understand patients with schizophrenia?

In answering this question through our own collaborative auto-ethnographic project, we are able to offer a great deal of insight on the importance of reflexivity in the research process, whilst questioning our own positionality as academics and recognising our own biases and subjectivities that we bring as interested parties to the field of migrant entrepreneurship. In essence, in this article we argue that whilst lived experience as a migrant can provide researchers with an advantage in interpreting data to theorise about the migrant entrepreneurship phenomenon, a researcher's ethnographic account represents only one of the multiple possible interpretations. Therefore, the contribution of this paper is in offering a reflection about the value of ethnography for developing migrant entrepreneurship scholarship, and how within this methodology the scholars' understanding of the need for specific sensitivities and reflexivities may result in enriched findings and understandings of migrant entrepreneurship phenomena. As such, this paper will be of interest to academics who seek new approaches to understand complex dynamics related to entrepreneurial migrants.

\section{Theoretical background}

\section{Migrant entrepreneurship}

Emerged over a number of decades, the literature on migrant entrepreneurship is undergoing a revival and merits scholarly attention due to globalization, everincreasing migration flows, and the recent demographic crisis caused by political turmoil in a number of regions of the world on one side, the recent health crisis caused by the COVID-19 pandemic, and the push of neoliberal discourses that place responsibility for survival through work and business start-ups upon displaced individuals in many economies affected by flows of migration and developed countries' priorities on finding ways to cope with the new ways of working under pandemic conditions.

Recent works on migrant entrepreneurship (see Vershinina and Rodgers 2019a, for a review) have started to look beyond the well-established studies of migrant entrepreneurship in the developed countries settings of the Global North and started to recognize the need to better understand the migrant entrepreneurship experiences that are happening beyond this narrow remit and locality. A number of topics have emerged as particularly pertinent to reflecting the realities of new waves of migration driven by the inability of individuals to survive in war-torn countries' contexts, who flee their countries in search of safety and improvements of livelihoods for themselves and their families. Whilst these topics are really important and reflect contemporary challenges of migration and integration, what can be observed is that the methods adopted for studying these populations seem to replicate what has been done in the early studies of economic migration (Light et al. 1994; Light 2004; Portes and Jensen 1989), from developing countries into developed economies. Such works, whilst still being relevant 
in identifying and signposting the motivations for migration and business start-ups of individuals with varied levels of resources that migrants can mobilize, foreground the Western contexts as a host environment with their specific structural conditions, which are mainly seen as discriminatory, and therefore migrants are portrayed in these works as individuals with very little agency (Giddens 1986).

Over the last 10 years, there have been significant changes in the way that migrant communities have been theorized (Vershinina et al. 2011; Elo et al. 2018; Ram et al. 2008; Rodgers et al. 2019; Vershinina and Rodgers 2019a, b). Various theoretical approaches have led to different debates and new conceptual understandings. A growing body of scholars has made progress in understanding how migrant communities can be studied through processual and contextualized views (Vershinina and Rodgers 2019a; Discua Cruz and Fromm 2019). Such advances have encouraged a view of migrant communities as dynamic and evolving, recognizing the importance of migrant individuals, their voices, their heterogeneous stories, and their embedded agency. Grounding research around migrant communities has revealed how practices are produced and reproduced, and have encouraged the emergence and adoption of more in-depth, qualitative, biographical methodological approaches (Vershinina and Rodgers 2019a; Elo et al. 2019), which go beyond individual experiences and examine migrant entrepreneurship journeys through the lens of household context, as well as beyond co-ethnic communities, re-focusing the attention on the co-migrant communities (Rodgers et al. 2019; Vershinina and Rodgers 2019a, b). These studies highlight the need for the adoption of immersive methods that have the capacity to bring forth new insights about the livelihoods and experiences of migration and entrepreneurship by migrants, which have previously been inaccessible, hidden, or untapped.

Yet while the topics of migration and entrepreneurship can be engaged through diverse methods, we should never assume that a particular method of research, whether quantitative or qualitative, is better than the other when studying migrant entrepreneurship. The relevance of a particular method depends primarily on the research question and the use of appropriate research design methods (Bryman 2004). Both qualitative and quantitative studies can contribute strongly to migrant entrepreneurship research (Vershinina and Rodionova 2011). On one hand, studies addressing "how" and "why" questions are relevant when untangling the complexities of underlying processes of migrant communities that influence entrepreneurial activity (Barrett and Vershinina 2017). On the other hand, survey data and statistical methods allow answering the "what" type of questions (Bryman 2004) in migrant studies (Rodríguez-Pose and von Berlepsch 2020). Both approaches can help study diverse research paths within the migrant entrepreneurship field.

In this study we focus on the opportunities and limitations of ethnography. While some works highlight the relevance of ethnography as both a methodological approach to - and an analytic perspective on - social research, others suggest that it might seem to lack standardized forms, both with respect to field research and analysis/narration (Van Maanen 1990, 2006, 2011). Prior studies have suggested that ethnography relies on the intertwined features of a method (e.g., the method of participant-observation) and a methodology (e.g., making sense of how others make sense of the world) (Brewer 1994; Geertz 2000:56-58): The methodological goal of focusing on sense-making practices demands some kind of data collection technique that accounts for the 
involvement of the researcher in, and with, the subject of study (Jackson 2006). By observing and assessing the methods adopted in migrant entrepreneurship we can reveal a key drawback, as the field has developed by relying on survey-based data, which funnels a specific set of perspectives and theoretical approaches through testable hypotheses, which are generalised. But, in doing so, these studies produce more unifying accounts of migration and entrepreneurship, thereby making the livelihoods of individuals, whose diverse experiences are being investigated, absent from the research, and thereby eliminating the centrality of context. These methodological approaches are limited in connecting personal experience with a more nuanced understanding of the underlying and relevant processes (Vershinina and Rodgers 2019a; Discua Cruz and Fromm 2019) that migrants experience as they learn to overcome the liabilities of foreignness and engage in entrepreneurship as the only possible economic option for them. The same set of methodologies has been adopted in studies of migrant communities, where the need for more critical methodologies and greater reflexivity in research design and practice is starting to be recognized (Discua Cruz and Cerrato 2019). In recent studies, scholars call for empirical studies in migrant entrepreneurship that consider drawing more widely on accounts of migrants' experiences in the micropractice of the everyday, and to adopt a broad critical intent (Fromm et al. 2020; Discua Cruz and Fromm 2019). Such a methodological focus offers researchers an opportunity to explore new investigatory techniques that challenge dominant theoretical understandings and produce more relevant insights, reflective of the heterogeneity of migrant populations and the more contemporary challenges that they encounter and overcome.

\section{Ethnography and its importance}

Ethnography as a methodology is being adopted across a wide range of topics in business and management studies, strategy as practice and, which is particularly important for entrepreneurship, as practice studies (Chalmers and Shaw 2017; Gartner et al. 2016). Recent studies suggest that entrepreneurship research calls for further in-depth insight into the everyday (Welter et al. 2017), mundane aspects of entrepreneurship (van Burg et al. 2020). Such mundanity does not exclude migrant entrepreneurs in the way they go about starting ventures in the places where they reside or move between (Evansluong and Ramírez-Pasillas 2018). The outcome of entrepreneurial processes for migrants points towards focusing on a better understanding of the motivation of individuals; for instance: necessity as opposed to opportunity-based entrepreneurship, (Dencker et al. 2019), teams (Ben-Hafaïedh and Cooney 2017), and families (James et al. 2020). As scholars call to advance our understanding of entrepreneurship by migrants around the world (Elo et al. 2018; Guerrero and Wanjiru 2019), there is an opportunity to focus on the approach and rationale of future studies. Van Burg et al. (2020) argue that qualitative research is especially well positioned to extend our understanding about the aspects that are hard to measure, like sensemaking, entrepreneurial identity, perseverance, family embeddedness, and the day-to-day small variations in entrepreneurial behaviour. Moreover, as suggested by van Burg and colleagues, attending to mundane entrepreneurial practices also goes beyond ontological individualism that would focus on what migrant entrepreneurs do, and rather draws attention to relational, embodied, mediated, and organized aspects of these practices (Thompson et al. 2020), situating the individual migrant entrepreneur within her or his 
entrepreneurial context. Such an approach would call for further attention to be given to collective research approaches of migrants to entrepreneurial opportunities.

Van Burg et al. (2020) advocate that ethnographic methodologies are wellsuited to study such everyday entrepreneurial activity. They argue that these approaches allow researchers to immerse themselves in a research site for a substantial period of time, where the minutiae of entrepreneurial life can be captured. Such approaches are relevant, as they overcome the challenges of interviews or diaries, as well as reliance on retrospective accounts or surveys. Ethnographic methods in general are relevant in the study of migrant entrepreneurship, as the experience and long exposure of the ethnographer to the field of study (together with the researcher's reflexive positionality) can serve diverse purposes. Ethnographic studies have gained widespread acceptance in diverse fields of study, and such studies have highlighted various approaches that allow researchers to combine techniques to approach a subject of study (e.g., Levitt 2001; Visconti 2010). Thus, it is important to consider the opportunities and limitations of ethnographic methods, as well as the relevance of insight that these methods produce as inquiry lenses in the field of migrant entrepreneurship.

Scholars agree that the advantages of ethnographic approaches relate to their ability to make visible the "real" sociality of a setting (Wolcott 1999). As such, the value of ethnography lies in the richness of the contextual approach (Cappellaro 2017). As a mode of research, ethnography is concerned with producing the detailed descriptions of the "everyday" activities of actors within specific contexts. It relies upon the collection of materials based on the first-hand experience of researchers immersed in a setting and their active ability to listen to diverse social actors (Forsey 2010). It allows presenting a portrait of a setting through the direct involvement of the researcher and how this can be understood by those involved in that setting. Hammersley (2015) suggests that the task of ethnographers is to document the culture, perspectives, and practices of the people in settings and understand the way that such groups of people see the world. However, the use of ethnography is not without some problems. Earlier works by Brewer (1994) highlighted that critiques of ethnography have revolved around the reliability of ethnographic description: that findings cannot be generalised or that they neither adequately test or generate theory, and so they may be theoretically naïve. Some of the criticism relates to the study of only parts of people's lives over relatively short time periods, as well as problems of sampling and generalisation, and a danger of failing to recognise both cyclical variability and change patterns (Hammersley 2006).

While examples of ethnographic studies can be found in several social disciplines, where they tend to be more prevalent, the use of ethnographic methods has begun to be increasingly adopted in the study of ethnic communities and migrants (e.g., Bovenkerk and Ruland 1992; Hall 2015; Smart 2003; Verver et al. 2020), as well as the transnational features of their organisations (Bolzani et al. 2020; Bruni et al. 2004; Levitt and Lamba-Nieves 2010; Sinatti 2019). Yet, van Burg et al. (2020) advocate that less conventional approaches to studying entrepreneurship, such as autoethnography, merit more attention. Van Burg et al. (2020) suggest that autoethnography refers to "either an ethnography of one's own group, or to an ethnography that is highly reflective of the situatedness of oneself in the context of study, and thus is likely to be more transparent about the role of the researcher than other methods" (Fletcher 2011). Such a depiction underscores the relevance of reviewing ethnography as a way to allow researchers to 
leverage their own personal connection and experience with migrant entrepreneurship. Based on such a call, we position the remainder of our study in autoethnography and present our own reflections as a relevant ethnographic approach for the study of migrant entrepreneurship.

\section{Autoethnography and its relevance for the study of migrant entrepreneurship}

In recent years, autoethnography has become a significant and legitimate method in many disciplines and research contexts (Holman Jones et al. 2013). Autoethnography broadly relates to a qualitative approach that helps describe and systematically analyse (graphy) personal experience (auto) in order to understand the embedded cultural experience (ethno) (Adams et al. 2014). The term was first used to describe a method of ethnographically studying a group of which we are part (Khosravi 2010). Nowadays, while it encompasses a multitude of approaches and writing forms, researchers agree that autoethnography gravitates around the use of personal experience to examine and/ or critique cultural experience (Adams et al. 2014, p. 22). In essence, autoethnography is a research method that relies on lived experiences connected to the broader social and cultural context, and thus can contribute to knowledge by theorising experiences so that they become embedded in theory and practice (McIlveen 2008).

Adams et al. (2014, p. 1-2) suggest autoethnography's relevance in the study of migrant entrepreneurship for several reasons: firstly, it uses a researcher's personal experience to describe and critique cultural beliefs, practices, and experiences. Secondly, it acknowledges and values a researcher's relationships with others. Thirdly, it uses deep and careful self-reflection - typically referred to as "reflexivity" - which helps researchers to name and interrogate the intersections between their self and the social context within which they are positioned. Fourthly, autoethnography showcases people through the process of figuring out what they do, how they live, and the meaning of their struggles. Finally, it balances intellectual and methodological rigour, emotions, and creativity. In the context of migrant entrepreneurship, we argue that autoethnography allows the generation of "theoretically relevant descriptions of a group to which one belongs, based on a structured analysis of one's experiences and the experiences of others from one's group" (Karra and Phillips 2008, p. 7).

The underlying features of autoethnography lie in its combination of ethnography and autobiography, as well as its methodological and theoretical rigor, which illuminates aspects of a cultural experience and makes both (culture and experiences) familiar to others (Ellis et al. 2011). Autoethnography may appear comparable to ethnography, first in terms of following a similar ethnographic research process by systematically collecting, analysing, and interpreting data, and second in attempting to achieve cultural understanding through analysis and interpretation (Chang 2016, p. 47). Yet, autoethnography differs from ethnographic inquiries in that researchers, as autoethnographers, also use their personal experiences as primary data. Chang (2016) argues that the richness of autobiographical narratives and autobiographical insights is valued within research, as it is intentionally integrated into the research process, unlike conventional ethnography. As such, autoethnography celebrates individual stories framed in the context of a bigger story, a story of a society, which makes autoethnography ethnographic. In so doing, autoethnography has the potential to focus 
on human connections and emphasize the importance of embedded personal stories (Doty 2010).

Autoethnography, therefore, is a relevant approach to challenge the status quo of researching migrant entrepreneurship because it is a reflexive tool by which a researcher can consciously embed himself or herself into theory and practice, and by way of an intimate autobiographic account, based on personal lived experiences, explicate a phenomenon under investigation or intervention (McIlveen 2008; Adams et al. 2014; Holman Jones et al. 2013). Autoethnography provides a migrant entrepreneurship researcher with a method for exploring and understanding personal experiences in relation to the experiences of others (e.g., migrants, diasporas, refugees) (Adams et al. 2017). Chang (2016, p. 52) suggests that methodologically speaking, autoethnography is a suitable method for the migrant entrepreneurship researcher, particularly when the researcher is a migrant him/herself. It can allow researchers easy access to the primary data source from the beginning, as the source is the researchers themselves. This occurs because in autoethnography, "proximity, not objectivity, becomes an epistemological point of departure and return and thus autoethnographers are privileged with a holistic and intimate perspective on their "familiar data"' (Adams et al. 2014, p. 23). This initial familiarity gives autoethnographers who are migrants an edge over other researchers in data collection, affording a development of trust between research participants and the research, as well as in-depth data interpretation. Adams et al. (2014) advocate that underlying reasons for migrant entrepreneurship researchers to engage in autoethnography may relate to their desire to: critique, make contributions to, and/or extend existing research and theory; disrupt taboos, break silences, and reclaim lost and disregarded voices; and finally, make research accessible to multiple audiences.

\section{Autoethnographic account of studies through the eyes of migrant scholars}

Across several fields, scholars have used exemplars of studies produced to explain the relevance of a particular methodology. Such an approach style helps provide practical examples of methodological approaches for studying migrant communities and discussing the impact of methodological decisions. It also assists in exploring methodological challenges and comparing these with areas of debate identified within existing literature, and in discussing practical implications that may support methodological decision making in future studies (see Larty and Hamilton 2011; Leppäaho et al. 2020; Pollock et al. 2017). In this particular study, and due to space constraints, we focus on recent collaborative works by Vershinina and Rogers (2019a), conducted through multi-site ethnography (Marcus 1995), and Discua Cruz and Fromm (2019) through auto-ethnography.

\section{Exemplars that focus on everyday gendered experiences of migrant entrepreneurs}

In Vershinina and Rodgers (2019a), the researchers set out to examine the gendered nature of migrants' lived experiences of setting up enterprises in the UK. This article's motivation was linked to the new stream of work that examines the role of gender in entrepreneurship research, with the aim to develop new insights on how the experience of migrant entrepreneurship is also gendered. In the paper we drew upon the voices of forty-seven Eastern European transnational migrant entrepreneurs: twenty-five men and 
twenty-two women. Generally, qualitative samples tend to be smaller, and this paper showcases a larger than average qualitative sample with sample population, which is rarely included in research on migration.

There exists a set of general accounts of entrepreneurship that position men as the norm and women as the "other" (Ahl and Marlow 2012; Marlow and McAdam 2012), as women's roles within entrepreneurship tend to be gendered, and are unconsciously reproduced as unrecognized and/or invisible. Scholars have called for a shift in the focus away from a narrative of "invisibility", which presents migrant women as uneducated, illiterate, and passive (Pio and Essers 2014). In our article we have focused on the development of new insights into the everyday experiences of transnational migrant men and women entrepreneurs in the UK by specifically recognizing the active agency of women, who are negotiating gendered societally imposed norms whilst operating across transnational spaces. Very little scholarly attention has been paid to the gendered nature of migrant entrepreneurship, and the theoretical development of the concept of migrant entrepreneurship has also been trapped in a normative explanation relating to male entrepreneurs. In our article we adopted Bourdieu's "forms of capital" approach (Bourdieu 1986; Vincent and Pagan 2018). There are a number of studies that adopt this theoretical lens to explain how migrant entrepreneurs mobilise different forms of capital (Baltar and Icart 2013; Pluess 2011; Vershinina et al. 2011) to further their business ventures. However, we have specifically focused on a rarely discussed form of symbolic capital, defined as prestige, status, and positive reputation that individuals possess in the eyes of others (Pret et al. 2016). Whilst men and women may both possess elements of symbolic capital, little has been written on symbolic capital as gendered capital, and the reality of the positive effects of prestige, status, and a positive reputation upon men and women. Inherently, as researchers, we were intrigued about the gendered nature of this concept, and we were fuelled by curiosity to find out if what we know about it applies to both migrant men and women.

As a migrant individual in the UK, an academic and a woman, the first author realized that a lot of the work that Bourdieu (1986) and others have written about the dimensionality of symbolic capital, as well as benefits that individuals derive from exercising this form of capital, may apply to men of a particular social class and status, but this may not be transferrable to the explanations of experiences of migrants, particularly women. This realization was very much a reflection on the current state of the literature, characterized by blindness of studies towards gendered structures, gendered processes, and the overarching gendered regimes (Jones et al. 2019) within which women operate. Being an Eastern European migrant and a scholar also brings forth a set of cultural interpretations of specific theoretical constructs that are helpful in recognizing the flaws of theoretical explanations. As a scholar and a migrant operating across multiple countries, the first author had an implicit understanding that transnationalism for my interviewees creates tensions between embedded notions of identity of their home country, whether the participants were Latvian, Russian, Belarusian, Moldovan, Ukrainian, or Lithuanian, with the power dynamics of home and the host environment and the recognition of agency by individuals operating across transnational spaces (Grewal and Kaplan 1994). Of course, as researchers we know that entrepreneurship experiences are heterogeneous (Marlow et al. 2009), and the location (home and host) produces sets of local gender regimes, whist individuals act in specific ways in responses that could constrain their business venturing. This is especially the 
case for women, who are constantly engaged in legitimacy building for themselves and their ventures whilst reconciling their gender and work-related role dissonance.

As both myself and my co-author are Russian speakers, and both of us have had experience of growing up or living in the Soviet Union, it was evident to us that in the narratives of our participants we could reveal the cultural markers of a shared Soviet past which, despite the break-up of the Soviet Union, continued to play an important role in our respondents' everyday practices. These shared cultural understandings and practices also enabled mobilisation of different forms of capital for migrant enterprises in the UK from within the co-ethnic and co-migrant networks, as well as from their transnational networks beyond the borders of their home countries. In our analysis we could see how continued and constant use of the Russian language, as a mechanism to identify "nash" - "one of us", helped migrants to embed themselves into co-migrant networks in the UK. These networks were not centred around ethnicity and country of origin, as scholars have previously thought (Ram et al. 2008; Vershinina et al. 2011). We found that the Russian language acted as a conduit for network operation, transcending layers of ethnicity and liabilities of foreignness, and helped to create specific cultural bonds between co-migrants with shared migration experiences and experiences of marginalisation in the new host environment. The narratives of the participants echoed our stories to some degree, and the other stories of migrant entrepreneurship that the first author has researched over the last 12 years.

The level of reflexivity and deep connection that the first author felt towards the participants of this study has helped us to uncover specific processes related to symbolic capital mobilization that a group of forty-seven Eastern European transnational migrant entrepreneurs adopted in order to pursue entrepreneurial endeavours in the UK. As a result of being able to emphasise with the accounts of the migrants and overlapping personal stories of migration and marginalization, we were able to recognize that social capital was something unchallenged, assumed, and possessed by migrants, but in our analysis we could show that our participants were leveraging symbolic capital from the practical workings of social capital as well as their power and personal legitimacy that was built in the eyes of others. Theoretically, this meant advancing theory and showcasing the linkages between various forms of capital and their convertibility (Light 2004). From the stories of the migrant entrepreneurs we could show that they were able to utilise social networks within co-ethnic and comigrant groups in the UK, using "blat" networks, a system of informal exchanges based on favours, across transnational spaces, and these processes happened in conjunction with symbolic capital. But the tools and elements of symbolic capital were gendered, as the narratives of male respondents revealed that symbolic capital acts as wholly facilitating for men through the bestowing of unquestioned status and prestige. For women migrant entrepreneurs in our sample, symbolic capital represented a constant battle for legitimacy, without any certainty that it may be achieved. Similar to my own struggles in battling for legitimacy as a migrant and a scholar, we could decipher that symbolic capital manifested in both constraining as well as facilitating effects for women.

Reflecting on the key findings and contributions of the article, one might argue that these autoethnographic accounts reveal subjectivities and positionalities involved in the researcher's life story that may affect the lens through which the researchers interpret the life trajectories of their study subjects. In this article I could support and justify the 
theoretical argument that for migrant men engaged in entrepreneurship in the UK, their leveraged symbolic capital acted as a "top-up" to their existing legitimized and normalized existence within the business milieu; however, migrant women developed their businesses in the UK with the sole purpose to justify and legitimate their existence in the UK, far away from their home countries, where their extended families and associated responsibilities were, which they continually negotiated. In the study we found support for the idea that for migrant women, only when their UK-based business became successful were they able to legitimize their existence in the UK as business owners in the eyes of their co-migrants in the UK and, crucially, their family and support networks across transnational spaces. What was clear is that leveraged symbolic capital for migrant women acts as a "baseline" to overcome rather than a "top-up" to enjoy. In conversation with us, our respondents recognized self-worth and reaffirmed confidence in their business, which also brought a realisation of active agency that they could exhibit and show how it had been achieved. In essence, through reliving their stories through deeply engaged conversations with the participants, I could unearth the alternative manifestation of symbolic capital and therefore develop theoretical insights that explain what enables migrant women (those that do succeed) to challenge traditional gendered roles, which had been ascribed and embedded in their home countries, and simultaneously bestow upon them "visibility" and showcase their active agency. These novel ideas could only have been developed as a result of being "familiar" with their context (Adams et al. 2014: 23), being reflexive about the stories they told, as well as making sense of them through my own migrant experience. Furthermore, reflection on the appropriateness of the method used became apparent, as the research process in this project can be called a multi-site ethnography (Marcus 1995), involving multiple sites and mobilities of researchers and their subjects as well as simultaneous embeddedness of researchers and subjects in the structural contours of multiple research sites. This represents a useful way to frame and conduct revelatory research on the transnational nature of migrant entrepreneurship.

\section{Exemplars that focus on diaspora communities and embedded forms of social capital}

In Discua Cruz and Fromm (2019), researchers set out to understand the concept of diaspora and its relationship to migrant entrepreneurship. In our study, diaspora relates to individuals and members of networks, associations, and communities who have left their country of origin but maintain links with their homelands (Safran 1991). Such conceptualization comprises settled expatriate communities, migrant workers based abroad temporarily, expatriates with the nationality of the host country, dual nationals and second-/third-generation migrants (Brubaker 2005; OECD 2012). Dispersion in space and orientation to a "homeland" characterize diasporas (Brubaker 2005). Dispersion can be either forced or voluntary, crossing or within state borders. Orientation to a homeland relates to a source of motivation, identity, and loyalty, reflected by a collective memory about the homeland and a commitment to its development or restoration (Brubaker 2005). Such a conceptualization was appealing to the involved researchers as migrants because we considered ourselves members of the Honduran diaspora. Such a concept allowed the second author to reflect on particular activities carried out by a group of migrants in connection with their sentimental and social links with a country of origin (Siar 2014). 
By reflecting on our own experiences as members of a diaspora, we were able to set out an investigation of our personal experience in the creation of a social enterprise in Europe. In doing so we were able to link the diaspora concept to theoretical discussions around transnationalism and networks. This was relevant, as transnationalism refers broadly to the processes by which migrants create and preserve multiple economic, cultural, and social relationships that link them to their origin and host societies (Vertovec 2001). Accordingly, we were able to relate to recent diaspora discourses that reflected our experience relating to "...a sense of being part of an ongoing transnational network that includes dispersed people who retain a sense of their uniqueness and an interest in their homeland" (Shuval 2000, p. 44). By being members of a diaspora, and later on members of a social enterprise composed of Honduran skilled migrants, we felt connected to multiple national spaces and networks (Waldinger 2008). Such duality was characterized by a sense of living in one place while simultaneously remembering and/or desiring and yearning for another place (Shuval 2000). As a result, we were able to identify multiple relationships and motivations connecting Hondurans simultaneously to two or more transnational networks (Schlenker et al. 2017). The multiplicity of such relations allowed us to review current theoretical discussions and then identify the relevance of relationships between members of a Honduran diaspora and their homeland, as well as among diaspora members dispersed across nation states (Shuval 2000).

Based on personal experience as a migrant and founding member of Honduras Global Europa, the second author relied on Levitt $(1998,2001)$, who proposes that in addition to money, migrants can provide social remittances, defined as: "the ideas, behaviours, identities, and social capital that flow from host to sending country communities" (Levitt 2001, p. 54). Levitt (1998, 2001) argues that social remittances relate to normative structures (ideas, values, and beliefs), systems of practice (actions shaped by normative structures), and social capital (values and norms on which social capital is based, and social capital itself). As we examined such a concept, we felt identified with the view that such remittances are distinct from economic ones because they are conveyed interpersonally between individuals who learn of, adapt, and diffuse ideas and practices from their environment through roles in families, communities, and organizations (Levitt 2001).

The concept of social remittances represented a paradigmatic shift in migration scholarship because it called to move away from theorizing about diaspora contributions based on financial remittances (Lindley 2009) and to focus instead on intangible remittances (Lacroix et al. 2016). Whilst the importance of some of these exchanges promote migrant entrepreneurship (Rodgers et al. 2019), community development, and political integration (Lacroix et al. 2016), most literature on social remittances has focused on exchanges between migrants in specific locations within a host country (Boston, USA) and a developing country of origin (Miraflores, Dominican Republic). Reflecting on such items, we realized, as migrants ourselves, that what was less understood was how social remittances are transmitted by several highly skilled migrants from the same country dispersed around the world, and whether a collective social remittance approach would influence the emergence of a social enterprise.

In examining our own experiences as migrants and founders of a social enterprise, we could appreciate that the theoretical roots of social remittances intersected with the 
transnational and relational nature of diasporas. This view was also supported by our experience of maintaining strong transnational ties over sustained periods with family and friends in our country of origin, which became transgenerational in nature (Haas 2010 , p. 247). Such ties facilitate social remittance exchanges when migrants return to live in or visit their communities of origin, or when non-migrants visit their migrant friends or family in a host country, or through interchanges of letters, videos, cassettes, and telephone calls over time (Levitt 1998, p. 936), as well as through web technologies (Oiarzabal 2012). Migrants who have constant and pro-active interactions with host societies may be in a privileged position to combine and expand cultural ideas, practices, and relationships in order to later engage in social remittance exchange (Levitt 1998). As we had experienced such dynamics in our countries of residence (UK, Switzerland), we could examine our experiences in light of theoretical premises related to social remittances.

Most importantly, based on our experiences in the development of Honduras Global Europa, we identified a network activation pattern that resulted in the emergence of the social enterprise, which could serve as a template for other migrants who may be interested in setting up similar organisations around the world. By revisiting existing theoretical perspectives in the study of migrant entrepreneurship (e.g., social capital, network ties) we uncovered the mechanisms, based on social relations, that influence the activation pattern of highly-skilled migrants to create a social enterprise for the benefit of countries of origin. We noticed that while most studies of social remittances focus on the ideas and practices that individual migrants may transfer to a country of origin, socio-cultural exchanges may influence broader community development through "collective social remittances". Collective social remittances are exchanged by individuals in their role as organisational members and can be used in organisational settings (e.g., educational organizations, business associations, church groups, or political parties). Levitt and Lamba-Nieves (2011) suggest that this may occur by migrants gathering social and/ or financial remittances around particular projects or through the coordination of separate organizations. Diverse motivations may accompany social remittance exchange. For example, agreed tangible projects (e.g., building a sports complex) may arise due to the motivation of migrants to enjoy similar host country experiences in future visits, as well as social pressures to maintain family social capital in the country of origin (Levitt 2001). In our studies we identified several tangible projects engaged in over the last seven years that have reflected the interests and intentions of skilled migrants to support entrepreneurship-related tasks, as well as knowledge exchange through a social enterprise. Finally, based on the autoethnographic approach, we challenged previous perspectives of over-reliance on government intervention and provided evidence on how the transmission of collective social remittances can flow transnationally, making highly skilled migrants effective agents of knowledge circulation across borders.

The outcome of our study has advanced understanding about how and why highly skilled migrants from a developing country can engage in the emergence and development of a social enterprise.

Our study has underscored the influence of interrelated motivations in diaspora engagement studies that would have been misunderstood or remained overlooked had we not engaged in an autoethnographic study. 


\section{Discussion and concluding remarks}

This paper contributes to the literature on research methods and migrant entrepreneurship by shedding light on a research method such as ethnography, and multiple possibilities that such methods offers to scholars. We acknowledge the challenges of the ethnographic method. Minge (2013, p. 429) suggests that the challenges for the researcher in using this approach may relate first to the "messy, complex, and multiple realities and knowledge" and second to the "knowledge construction from a particular point of view within a particular context". Yet, our interpretation of Minge (2013) is that being part of a migrant community, being a gendered subject, or being part of a diaspora that is complex and complicated can reveal the messy and multiple intersections of knowledge and truth. There is also a need to recognize and reflect on subjectivities that are brought forth by researchers' own experience of migration and marginalization, ensuring that the respondents' voices form the story. Moreover, Anderson (2006) suggests that limitations can be found in the nature and interest of the involvement of researchers with their subject of study, and often an ethnographic approach will be difficult to engage in by members of the same migrant community, which highlights the importance of a collaborative approach. Chang (2016, p. 52) argues that researchers should consider the personal, relational, and institutional risks and responsibilities of doing autoethnography. Such engagement requires researchers to work with participants in a more participant-oriented way, treating participants of migrant communities respectfully before, during, and after research projects (Adams et al. 2014), as such behaviour results in a more trustworthy experience for both the researcher and the respondent.

In this article we have presented work that uncovers the social context of migrant entrepreneurship and connected it to the theoretical perspectives that inform and get extended as a result of these studies. We have used autoethnographic reflections and illustrations to highlight that if it was not for our personal reflexivity and recognition of our subjectivities and positionality as migrants, men, and women - and scholars - the perceived role of migrants could have remained unchallenged, and that changing our methodological view on how to design our research is critical. This insight is important because it allows new understanding of the complex narratives of migration dynamics to emerge from the respondents, so we can show how these narratives intertwine with their stories of entrepreneurship.

We argue that with ethnography, future studies can engage migrant entrepreneurship researchers in answering overlooked yet critical questions. For example, it can allow researchers across disciplines to understand how transnational enterprises emerge and develop. It can also allow the interpretation of stories told by migrant families in business (Hamilton et al. 2017), as well as further understanding of their approach to entrepreneurship (Discua Cruz et al. 2020), according to the researcher's personal perspectives, without removing themselves from what is being studied. Moreover, it can help understand the development of migrant or ethnic entrepreneurial groups over time and across contexts (Stamm et al. 2019; James et al. 2020), as individuals who act as "familiar" (Adams et al. 2014) (in this case as researchers) may indeed tap into the essence of what makes certain migrants and certain migration and integration trajectories unique. 
Migrant entrepreneurship scholars are starting to reveal the intricate processes that demand such perspectives (see Elo and Dana 2019) and incorporate elements of ethnographic reflexive methods into their research design. In addition, ethnographic approaches are becoming relevant to both access data and to reflect on social understandings about the way enterprises, composed of migrants, operate (Bolzani et al. 2020). Future studies can engage in analytic autoethnography (Anderson 2006), which demands: 1) at least one of the researchers is a complete member of the social world under study (e.g., a migrant); (2) analytic reflexivity; (3) narrative visibility of the researcher's self; (4) dialogue with informants beyond the self; and (5) commitment to theoretical analysis. In this way, autoethnography moves beyond an evocative nature and focuses on an analytic approach. Such an approach, as argued by Anderson (2006), provides clear advantages for migrant entrepreneurship researchers, such as multiple reasons and incentives to spend time in the field, facilitating access to data, vantage points to access certain types of data, and opportunities to draw upon personal experiences and perceptions in order to inform broader social understandings.

To further address analytic autoethnographic approaches of migrant entrepreneurship dynamics, scholars can focus on collaborative autoethnography (Chang 2013, 2016), where the expertise of an "interdisciplinary team" can be pulled together, drawing on diverse areas of expertise. Such an approach entails that the analysis of a particular phenomenon, as suggested by Chang, can be undertaken by all researchers involved, or partially, where one member engages in collecting the data (e.g., migrant researchers) and writing the autoethnographic text while the others help analyse the data. In a recent article by Jones et al. (2019), involving collaborative autoethnography, gender and entrepreneurship scholars have compiled a rich set of experiences of female scholars engaging in gender and entrepreneurship research whilst being based in UK business schools. Jones et al. (2019) reveal the politics of undertaking research in a subject area that is considered marginal by mainstream entrepreneurship scholars. Their paper serves as the first of many that critique and challenge the studies that strip out context, emotions, and deep connections with participants, and it calls for more work that engages the heart and not just the head. It is our belief that migrant entrepreneurship researchers can become actors in - and, most importantly, protagonists of - the study, and in doing so can understand the meaning of what they read, hear, think, feel, and do (Ellis et al. 2011) in terms of their experiences and the rich experiences of their respondents, and also delve analytically, based on their position as migrants or members of a migrant community (Anderson 2006). We hope this article will offer a new avenue for work on migrant entrepreneurship by migrant scholars who share the experience of migration, and therefore can become even better storytellers and lift the voices of the marginalized, so that these will be heard.

Moreover, further studies can follow new ethnographic methods that have not been discussed in this article. A systematic literature review of methodologies, including various types of ethnography, is necessary to identify gaps in methods and new research directions. Van Burg et al. (2020) highlight the importance of video ethnography, such as event-based (e.g., pitches) or participant-led videos and digital ethnography, which allows capturing digital interactions (e.g., email, Twitter and WhatsApp, Skype), which may help identify dominant and marginal voices in migrant entrepreneurship. We call for further studies that adopt (auto)ethnographic methods in migrant entrepreneurship. Such studies can, as have the papers in this special issue, extend our 
understanding of entrepreneurial migrants from/in emerging economies. We also acknowledge that more scholarly work is needed to incorporate cultural and historical variation of migration experiences and thus encourage researchers, particularly those from the Global South, to consider their personal experiences as a point of departure in their future academic work on migrant entrepreneurship.

\section{References}

Adams, T. E., Jones, S. H., \& Ellis, C. (2014). Autoethnography. Oxford University Press.

Adams, T. E., Ellis, C., \& Jones, S. H. (2017). Autoethnography. In the International Encyclopedia of Communication Research Methods (pp. 1-11). American Cancer Society. https://doi.org/10.1002/ 9781118901731.iecrm0011.

Ahl, H., \& Marlow, S. (2012). Exploring the dynamics of gender, feminism and entrepreneurship: advancing debate to escape a dead end? Organization, 19(5), 543-562.

Anderson, L. (2006). Analytic autoethnography. Journal of Contemporary Ethnography, 35(4), 373-395. https://doi.org/10.1177/0891241605280449.

Baltar, F., \& Icart, I. B. (2013). Entrepreneurial gain, cultural similarity and transnational entrepreneurship. Global Networks, 13(2), 200-220.

Barrett, R., \& Vershinina, N. (2017). Intersectionality of ethnic and entrepreneurial identities: a study of postwar polish entrepreneurs in an English city. Journal of Small Business Management, 55(3), 430-443.

Bruni, A., Gherardi, S., \& Poggio, B. (2004). Entrepreneur-mentality, gender and the study of women entrepreneurs. Journal of Organizational Change Management, 17(3), 256-268.

Bryman, A. (2004). Encyclopedia of social science research methods. Thousand Oaks: SAGE Publications.

Ben-Hafä̈edh, C., \& Cooney, T. M. (2017). Research handbook on entrepreneurial teams: Theory and practice. Cheltenham: Edward Elgar Publishing.

Bolzani, D., Marabello, S., \& Honig, B. (2020). Exploring the multi-level processes of legitimacy in transnational social enterprises. Journal of Business Venturing, 35(3), 105941. https://doi.org/10.1016/j. jbusvent.2019.06.002.

Bourdieu, P. (1986). The forms of capital. In J. Richardson (Ed.), Handbook of theory and research for the sociology of education (pp. 241-258). New York: Greenwood Press.

Bovenkerk, F., \& Ruland, L. (1992). Artisan entrepreneurs: two centuries of Italian immigration to the Netherlands. International Migration Review, 26(3), 927-939. https://doi.org/10.1177/ 019791839202600308.

Brewer, J. D. (1994). The ethnographic critique of ethnography: sectarianism in the RUC. Sociology, 28(1), 231-244. https://doi.org/10.1177/0038038594028001014.

Brubaker, R. (2005). The 'diaspora' diaspora. Ethnic and Racial Studies, 28(1), 1-19.

Cappellaro, G. (2017). Ethnography in public management research: a systematic review and future directions. International Public Management Journal, 20(1), 14-48. https://doi.org/10.1080/10967494.2016. 1143423.

Chalmers, D. M., \& Shaw, E. (2017). The endogenous construction of entrepreneurial contexts: A practicebased perspective. International Small Business Journal: Researching Entrepreneurship, 35(1), 19-39.

Chang, H. (2013). Individual and collaborative autoethnography as method. In S. L. Holman Jones, T. E. Adams, \& C. Ellis (Eds.), Handbook of Autoethnography (pp. 107-122). New York: Routledge.

Chang, H. (2016). Autoethnography as method. Abingdon: Routledge.

Dencker, J., Bacq, S. C., Gruber, M., \& Haas, M. (2019). Reconceptualizing necessity entrepreneurship: a contextualized framework of entrepreneurial processes under the condition of basic needs. Academy of Management Review. https://doi.org/10.5465/amr.2017.0471.

Discua Cruz, A., \& Cerrato, P. (2019). Understanding entrepreneurship and international business knowledge transfer by diaspora knowledge networks: the case of Honduras global. In M. Elo \& I. Minto-Coy (Eds.), Diaspora networks in international business: Perspectives for understanding and managing diaspora business and resources. Berlin: Springer International Publishing.

Discua Cruz, A., \& Fromm, I. (2019). Understanding the emergence of a social enterprise by highly skilled migrants: the case of Honduras global Europa. International Journal of Entrepreneurial Behavior \& Research, 25(5), 801-818. https://doi.org/10.1108/IJEBR-02-2018-0091. 
Discua Cruz, A., Hamilton, E., \& Jack, S. (2020). Understanding entrepreneurial opportunities through metaphors: a narrative approach to theorizing family entrepreneurship. Entrepreneurship and Regional Development, 1-22. https://doi.org/10.1080/08985626.2020.1727089.

Doty, R. L. (2010). Autoethnography - Making human connections. Review of International Studies, 36(4), 1047-1050.

Ellis, C., Adams, T. E., \& Bochner, A. P. (2011). Autoethnography: an overview. Historical Social Research / Historische Sozialforschung, $36(4$ (138)), 273-290.

Elo, M., \& Dana, L.-P. (2019). Embeddedness and entrepreneurial traditions: entrepreneurship of Bukharian Jews in diaspora. Journal of Family Business Management, ahead-of-print(ahead-of-print). https://doi. org/10.1108/JFBM-03-2019-0016.

Elo, M., Sandberg, S., Servais, P., Basco, R., Discua Cruz, A., Riddle, L., \& Täube, F. (2018). Advancing the views on migrant and diaspora entrepreneurs in international entrepreneurship. Journal of International Entrepreneurship, 16(2), 119-133. https://doi.org/10.1007/s10843-018-0231-x.

Elo, M., Servais, P., Sandberg, S., Discua Cruz, A., \& Basco, R. (2019). Entrepreneurship, migration, and family in peripheral contexts - Avenues for growth and internationalisation. International Journal of Entrepreneurship and Small Business, 36(1/2), 1-15. https://doi.org/10.1504/IJESB.2019.096973.

Evansluong, Q., \& Ramírez-Pasillas, M. (2018). The role of family social capital in immigrants' entrepreneurial opportunity creation processes. International Journal of Entrepreneurship and Small Business, 36(1-2), 164-188. https://doi.org/10.1504/IJESB.2019.096973.

Fletcher, D. E. (2011). A curiosity for contexts: entrepreneurship, enactive research and autoethnography. Entrepreneurship and Regional Development, 23(1-2), 65-76. https://doi.org/10.1080/08985626.2011. 540414.

Forsey, M. G. (2010). Ethnography as participant listening. Ethnography, 11(4), 558-572. https://doi.org/10. $1177 / 1466138110372587$.

Fromm, I., Cortez Arias, R., Bulnes, L. C., \& Discua Cruz, A. (2020). The role of social remittances in promoting transformative societal change. In: Social Innovation of New Ventures, Routledge.

Gartner, W. B., Stam, E., Thompson, N. A., \& Verduyn, K. (2016). Entrepreneurship as practice: grounding contemporary practice theory into entrepreneurship studies. Entrepreneurship and Regional Development, 28(9-10), 813-816.

Geertz, C. (2000). Local knowledge: further essays in interpretive anthropology (Third ed.). New York: Basic Books.

Giddens, A. (1984). The constitution of society: outline of the theory of structuration. Berkeley: Univ of California Press.

Giddens, A. (1986). The Constitution of society: outline of the theory of structuration. Berkeley: University of California Press.

Grewal, I., \& Kaplan, C. (1994). Scattered hegemonies: post- modernity and transnational feminist practices. Minneapolis: University of Minnesota Press.

Guerrero, M. and Wanjiru, R. (2019). Call for papers, International Entrepreneurship and Management Journal, Special Issue on Entrepreneurial Migrants From and in Emerging Economies.

Haas, H. D. (2010). Migration and development: a theoretical perspective 1. International Migration Review, 44(1), 227-264. https://doi.org/10.1111/j.1747-7379.2009.00804.x.

Hall, S. M. (2015). Super-diverse street: a 'trans-ethnography' across migrant localities. Ethnic and Racial Studies, 38(1), 22-37. https://doi.org/10.1080/01419870.2013.858175.

Hamilton, E., Discua Cruz, A., \& Jack, S. (2017). Re-framing the status of narrative in family business research: towards an understanding of families in business. Journal of Family Business Strategy, 8(1), 312. https://doi.org/10.1016/j.jfbs.2016.11.001.

Hammersley, M. (2006). Ethnography: problems and prospects. Ethnography and Education, 1(1), 3-14. https://doi.org/10.1080/17457820500512697.

Hammersley, M. (2015). Ethnography. In The Blackwell Encyclopedia of Sociology. American Cancer Society. https://doi.org/10.1002/9781405165518.wbeose070.pub2.

Holman Jones, S. L., Adams, T. E., \& Ellis, C. (Eds.). (2013). Handbook of autoethnography. Routledge. https://doi.org/10.4324/9781315427812.

Jackson, P. T. (2006). Making sense of making sense: Configurational analysis and the double hermeneutic. In D. Yanow \& P. Schwartz-Shea (Eds.), Interpretation and Method: Empirical Research Methods and the Interpretive Turn (pp. 264-280). Armonk: M. E. Sharpe.

James, A. E., Hadjielias, E., Guerrero, M., Discua Cruz, A., \& Basco, R. (2020). Entrepreneurial families in business across generations contexts and cultures. Journal of Family Business Management. Ahead-ofprint, https://doi.org/10.1108/JFBM-01-2020-0003, ahead-of-print. 
Jones, S., Martinez Dy, A., \& Vershinina, N. (2019). 'We were fighting for our place': resisting gender knowledge regimes through feminist knowledge network formation. Gender, Work and Organization, 26(6), 789-804.

Karra, N., \& Phillips, N. (2008). Researching "back home" international management research as autoethnography. Organizational Research Methods, 11(3), 541-561.

Khosravi, S. (2010). 'Illegal' traveller: an auto-ethnography of borders. Basingstoke: Palgrave MacMillan.

Kloosterman, R., van Leun, J., \& Rath, J. (1999). Mixed Embeddedness: (in)formal activities and immigrant businesses in the Netherlands. International Journal of Urban and Regional Research, 23(2), 252-266.

Kloosterman, R. C., Rusinovic, K., \& Yeboah, D. (2016). Super-diverse migrants-Similar trajectories? Ghanaian entrepreneurship in the Netherlands seen from a mixed Embeddedness perspective. Journal of Ethnic and Migration Studies, 42(6), 913-932.

Lacroix, T., Levitt, P., \& Vari-Lavoisier, I. (2016). Social remittances and the changing transnational political landscape. Comparative Migration Studies, 4(1), 16. https://doi.org/10.1186/s40878-016-0032-0.

Larty, J., \& Hamilton, E. (2011). Structural approaches to narrative analysis in entrepreneurship research. Exemplars from two researchers. International Small Business Journal, 29(3), 220-237. https://doi.org/ 10.1177/0266242611401796.

Leppäaho, T., Plakoyiannaki, E., Kampouri, K., \& Paavilainen-Mäntymäki, E. (2020). The case study in family business: Current perspectives and suggestions for the future. In Handbook of Qualitative Research Methods for Family Business. Edward Elgar Publishing.

Levitt, P. (1998). Social remittances: migration driven local-level forms of cultural diffusion. The International Migration Review, 32(4), 926-948.

Levitt, P. (2001). The transnational villagers. University of California Press.

Levitt, P., \& Lamba-Nieves, D. (2010). It's not just about the economy, stupid - Social remittances revisited. Migration Information Source, 21, 1-9.

Levitt, P., \& Lamba-Nieves, D. (2011). Social remittances revisited. Journal of Ethnic and Migration Studies, $37(1), 1-22$.

Light, I. (2004). Social capital's unique accessibility. Journal of the American Planning Association, 70(2), $145-151$.

Light, I., Sabagh, G., Bozorgmehr, M., \& Der-Martirosian, C. (1994). Beyond the ethnic enclave economy. Social Problems, 41(1), 65-80.

Lindley, A. (2009). The early-morning phone call: remittances from a refugee diaspora perspective. Journal of Ethnic and Migration Studies, 35, 1315-1334.

Marcus, G. E. (1995). Ethnography in/of the world system: the emergence of multi-sited ethnography. Annual Review of Anthropology, 24(1), 95-117.

Marlow, S., \& McAdam, M. (2012). Analyzing the influence of gender upon high-technology venturing within the context of business incubation. Entrepreneurship Theory and Practice, 36(4), 655-676.

Marlow, S., Henry, C., \& Carter, S. (2009). Exploring the impact of gender upon women's business ownership: introduction. International Small Business Journal, 27(2), 139-148.

McIlveen, P. (2008). Autoethnography as a method for reflexive research and practice in vocational psychology. Australian Journal of Career Development, 17(2), 13-20.

Minge, J. M. (2013). Mindful autoethnography, local knowledges: Lessons from family. In S. L. Holman Jones, T. E. Adams, \& C. Ellis (Eds.), Handbook of Autoethnography (pp. 425-442). New York: Routledge.

OECD (2012). Connecting with emigrants. Organisation for Economic Co-operation and Development. http:// www.oecd-ilibrary.org/content/book/9789264177949-en. Accessed 3 Nov 2020.

Oiarzabal, P. J. (2012). Diaspora Basques and online social networks: an analysis of users of Basque institutional diaspora groups on Facebook. Journal of Ethnic and Migration Studies, 38(9), 1469-1485. https://doi.org/10.1080/1369183X.2012.698216.

Parker-Jenkins, M. (2018). Problematising ethnography and case study: reflections on using ethnographic techniques and researcher positioning. Ethnography and Education, 13(1), 18-33. https://doi.org/10. 1080/17457823.2016.1253028.

Pio, E., \& Essers, C. (2014). Professional migrant women decentring otherness: A transnational perspective. British Journal of Management, 25(2), 252-265.

Pluess, C. (2011). Baghdadi Jews in Hong Kong: Converting cultural, social and economic capital among three transregional networks. Global Networks, 11(1), 82-96.

Pollock, A., Campbell, P., Brunton, G., Hunt, H., \& Estcourt, L. (2017). Selecting and implementing overview methods: Implications from five exemplar overviews. Systematic Reviews, 6(1), 145. https://doi.org/10. 1186/s13643-017-0534-3. 
Portes, A., \& Jensen, L. (1989). The enclave and the entrants: Patterns of ethnic enterprise in Miami before and after Mariel. American Sociological Review, 54, 929-949.

Pret, T., Shaw, E., \& Drakopoulou Dodd, S. (2016). Painting the full picture: The conversion of economic, cultural, social and symbolic capital. International Small Business Journal, 34(8), 1004-1027.

Ram, M., Theodorakopoulos, N., \& Jones, T. (2008). Forms of capital, mixed embeddedness and Somali enterprise. Work, Employment and Society, 22(3), 427-446.

Rodgers, P., Vershinina, N., Williams, C. C., \& Theodorakopoulos, N. (2019). Leveraging symbolic capital: The use of blat networks across transnational spaces. Global Networks, 19(1), 119-136.

Rodríguez-Pose, A., \& von Berlepsch, V. (2020). Migration-prone and migration-averse places. Path dependence in long-term migration to the US. Applied Geography, 116, 102157. https://doi.org/10.1016/j. apgeog.2020.102157.

Safran, W. (1991). Diasporas in modern societies: Myths of homeland and return. Diaspora: A Journal of Transnational Studies, 1(1), 83-99. https://doi.org/10.1353/dsp.1991.0004.

Schlenker, A., Blatter, J., \& Birka, I. (2017). Practising transnational citizenship: dual nationality and simultaneous political involvement among emigrants. Journal of Ethnic and Migration Studies, 43(3), 418-440. https://doi.org/10.1080/1369183X.2016.1185941.

Shuval, J. T. (2000). Diaspora migration: definitional ambiguities and a theoretical paradigm. International Migration, 38(5), 41-56. https://doi.org/10.1111/1468-2435.00127.

Siar, S. (2014). Diaspora knowledge transfer as a development strategy for capturing the gains of skilled migration. Asian and Pacific Migration Journal, 23(3), 299-323. https://doi.org/10.1177/ 011719681402300303.

Sinatti, G. (2019). Return migration, entrepreneurship and development: contrasting the economic growth perspective of Senegal's diaspora policy through a migrant-centred approach. African Studies, 78(4), 609-623. https://doi.org/10.1080/00020184.2018.1555310.

Smart, J. (2003). Ethnic entrepreneurship, transmigration and social integration: an ethnographic study of Chinese restaurant owners in rural Western Canada. Urban Anthropology and Studies of Cultural Systems and World Economic Development, 32(3/4), 311-342.

Stamm, I., Discua Cruz, A., \& Cailluet, L. (2019). Entrepreneurial groups: definition, forms, and historic change. Historical Social Research, 44(4), 7-41.

Thompson, N. A., Verduijn, K., \& Gartner, W. B. (2020). Entrepreneurship-as-practice: grounding contemporary theories of practice into entrepreneurship studies. Entrepreneurship and Regional Development, 32(3-4), 247-256. https://doi.org/10.1080/08985626.2019.1641978.

van Burg, E., Cornelissen, J., Stam, W., \& Jack, S. (2020). Advancing qualitative entrepreneurship research: leveraging methodological plurality for achieving scholarly impact. Entrepreneurship, Theory and Practice (earlycite).

Van Maanen, J. (1990). Great moments in ethnography: an Editor's introduction. Journal of Contemporary Ethnography, 19(1), 3-7. https://doi.org/10.1177/089124190019001001.

Van Maanen, J. (2006). Ethnography then and now. Qualitative Research in Organizations and Management: An International Journal, 1(1), 13-21. https://doi.org/10.1108/17465640610666615.

Van Maanen, J. (2011). Ethnography as work: Some rules of engagement. Journal of Management Studies, 48(1), 218-234. https://doi.org/10.1111/j.1467-6486.2010.00980.x.

Vershinina, N., \& Rodgers, P. (2019a). Migration, enterprise and society. International Journal of Entrepreneurial Behavior \& Research, 25(5), 774-779. https://doi.org/10.1108/IJEBR-08-2019-818.

Vershinina, N., \& Rodgers, P. (2019b). Symbolic capital within the lived experiences of eastern European migrants: a gendered perspective. Entrepreneurship \& Regional Development, 1-16. https://doi.org/10. 1080/08985626.2019.1703045.

Vershinina, N., \& Rodionova, Y. (2011). Methodological issues in studying hidden populations operating in the informal economy. Social Policy, 31(11/12), 697-716.

Vershinina, N., Barrett, R., \& Meyer, M. (2011). Forms of capital, intra-ethnic variation and polish entrepreneurs in Leicester. Work, Employment and Society, 25(1), 101-117.

Vertovec, S. (2001). Transnationalism and identity. Journal of Ethnic and Migration Studies, 27(4), 573-582. https://doi.org/10.1080/13691830120090386.

Verver, M., Roessingh, C., \& Passenier, D. (2020). Ethnic boundary dynamics in immigrant entrepreneurship: a Barthian perspective. Entrepreneurship \& Regional Development, O(0), 1-26. https://doi.org/10.1080/ 08985626.2020.1757160.

Vincent, S., \& Pagan, V. (2018). Entrepreneurial agency and field relations: a realist Bourdieusian analysis. Human Relations, 72, 188-216. https://doi.org/10.1177/0018726718767952. 
Visconti, L. M. (2010). Ethnographic case study (ECS): abductive modeling of ethnography and improving the relevance in business marketing research. Industrial Marketing Management, 39(1), 25-39. https:// doi.org/10.1016/j.indmarman.2008.04.019.

Waldinger, R. (2008). Between "Here" and "there": immigrant cross-border activities and loyalties. International Migration Review, 42(1), 3-29. https://doi.org/10.1111/j.1747-7379.2007.00112.x.

Wei, X., \& Zhu, H. (2020). Return migrants' entrepreneurial decisions in rural China. Asian Population Studies, 16(1), 61-81. https://doi.org/10.1080/17441730.2020.1718358.

Welter, F., Baker, T., Audretsch, D. B., \& Gartner, W. B. (2017). Everyday entrepreneurship -A call for entrepreneurship research to embrace entrepreneurial diversity. Entrepreneurship Theory and Practice, 41(3), 311-321. https://doi.org/10.1111/etap.12258.

Wolcott, H. F. (1999). Ethnography: A way of seeing. Rowman Altamira.

Publisher's note Springer Nature remains neutral with regard to jurisdictional claims in published maps and institutional affiliations. 